\title{
MODERN TRANSLUCENT ENCLOSURES IN ARCHITECTURE
}

\author{
Oleg Fedorov", Victoria Lazina² \\ ${ }^{1,2}$ Saint Petersburg State University of Architecture and Civil Engineering \\ Vtoraja Krasnoarmeyskaya st., 4, Saint Petersburg, Russia
}

${ }^{1}$ Corresponding author: oleg_proart@mail.ru

\begin{abstract}
Introduction: The study addresses different types of translucent enclosures currently used in architecture and construction. Modern classifications of such structures and their disadvantages are described. The authors propose a classification combining and systematizing all existing types of translucent structures. They also provide examples of architectural objects where such solutions are implemented. Purpose of the study: The study aims to systematize and update classifications of different types of translucent enclosures, determine their role in the formation of architecture and the provision of an interaction between the internal and external space, to identify the form-generating potential of such structures. Methods: The authors applied a systemic, multi-factor approach to the matter under consideration, reviewed and systematized scientific as well as architectural-and-design sources to analyze buildings designed with account for the use of translucent facade structures. They describe all types of such structures and provide a table with projects of well-known architects and corresponding drawings where the described types of facade systems are used. Results: The authors identified the form-generating potential of glass structures, analyzed the role of translucent enclosures in the formation of architecture and the provision of an interaction between the internal and external space, and developed a new classification for modern types of translucent facades with account for architectural-and-design characteristics.
\end{abstract}

\section{Keywords}

Translucent enclosures, light, glass, facade, facade glazing system, classification.

\section{Introduction}

Glazed facades have become an important element of modern architecture. The amount of light penetrating a building through translucent structures is an essential criterion for the assessment of space quality. Therefore, to create harmonious architecture, it is required to study ways of working with light. Besides, such studies shall be comprehensive in nature (Fedorov et al., 2015). Facade glazing not only has particular light-transmitting properties but provides a spatial layout that defines the appearance of a modern building. Being a tool of aesthetic transformation, the glass transforms not only the urban environment but the interior environment as well: visually, space becomes lighter, the contact with nature is achieved, an artistic and compositional play of light and shadow occurs.

When developing translucent facade solutions, due to high aesthetic potential, functional significance and variety of design solutions, architects shall be familiar with the full range of design variations, their advantages and capabilities. Facades with translucent glazing significantly affect the building appearance and architecture. The exceptional importance of glass as a material and translucent facades as a design solution can be explained by specific properties of glass distinguishing it from other materials. Such properties include the following: transparency, reflectance, geometric clarity, decorativeness (decorative capabilities) (Fedorov, 2007; Fedorov and Lazina, 2018). Due to the efficient use of these properties, it is possible to solve all kinds of architectural and artistic tasks and develop various conceptual designs.

Through the use of the transparency of external structures, the interaction between the interior of a building and its exterior, as well as people outside, can be ensured. A glazed surface allows us to "look inside". It symbolizes the "openness" of an establishment / "transparency" of processes occurring inside or draws the attention of people outside to the interior design. A principle of communion with nature is implemented.

As for reflectance, any glass has such a property. The degree of reflectance, which is a defining characteristic, ranges from the minimum to the maximum. The reflectance property allows buildings to "merge" with the environment as the landscape and daylight depending on time and weather are reflected by glazed surfaces. Using this property, it is possible to achieve interesting artistic and compositional effects when glazed surfaces reflect various elements and parts of a facility.

Geometric clarity can provide extremely smooth surfaces, absolutely flat lines and faces of facade elements, or geometric perfection of doubly curved 
shapes. These properties and features of glass, allowing us to sculpt the facade composition and individual details, as well as two-dimensional capabilities of the material, make it possible to create a unique building envelope using modern translucent enclosures and ensure geometric clarity of lines and faces.

Decorative characteristics involve the possibilities of creating artistic translucent compositions, colored and tinted glasses, or glass reliefs, print various images on glass, etc. Using these, it is possible to give architecture both an artistic and conceptual verbal meaning. Among other things, space is enriched, architecture becomes more complex, expression of an artistic form intensifies due to the use of more complex lighting configurations (coloring and refraction of the rays of natural light) (Fedorov and Lazina, 2018).

As there is a variety of visual and conceptual characteristics, and translucent enclosures have a high form-generating potential, it becomes necessary to provide a classification of translucent structures, convenient for architects.

Existing classifications of current types and methods of glazing (based on different sources) are presented below.

State Standard GOST 33079-2014 "Translucent enclosing structures. Classification. Terms and definitions" offers the following classification (Table 1):

Table 1. Classification of translucent facade structures

\begin{tabular}{|c|c|}
\hline Classification criteria & Types \\
\hline 1. Location of the structure: & $\begin{array}{l}\text { - suspended structure; } \\
\text { - integrated structure; } \\
\text { - combined structure. }\end{array}$ \\
\hline 2. Type of the load-bearing frame: & $\begin{array}{l}\text { - mullion-transom structure; } \\
\text { - modular structure; } \\
\text { - post and beam structure; } \\
\text { - cable structure; } \\
\text { - frameless structure; } \\
\text { - combined structure. }\end{array}$ \\
\hline 3. Material of the frame: & $\begin{array}{l}\text { - steel frame; } \\
\text { - aluminum alloy frame; } \\
\text { - timber frame; } \\
\text { - laminated glass frame; } \\
\text { - plastic frame; } \\
\text { - combined frame. }\end{array}$ \\
\hline $\begin{array}{l}\text { 4. Type of translucent cladding } \\
\text { attachment: }\end{array}$ & $\begin{array}{l}\text { - mechanical attachment with external pressure plates along all or several } \\
\text { cladding edges; } \\
\text { - mechanical attachment with internal pressure plates along all or several } \\
\text { cladding edges; } \\
\text { - mechanical attachment with external/internal point fixations in the form of } \\
\text { clamps along all or several cladding edges; } \\
\text { - mechanical attachment with external/internal point fixations in the form of } \\
\text { bolted bearings; } \\
\text { - glued (adhesive) attachment along all edges of translucent cladding; } \\
\text { - glued (adhesive) attachment along several edges of translucent cladding; } \\
\text { - combined attachment including two or more types of attachment. }\end{array}$ \\
\hline $\begin{array}{l}\text { 5. Availability of mechanical attachment } \\
\text { elements projecting from the glazing } \\
\text { plane: }\end{array}$ & $\begin{array}{l}\text { - with visible attachment elements; } \\
\text { - without visible attachment elements; } \\
\text { - combined. }\end{array}$ \\
\hline 6. Type of translucent cladding: & $\begin{array}{l}\text { - plate glass; } \\
\text { - laminated glass; } \\
\text { - glass units; } \\
\text { - profiled construction glass; } \\
\text { - translucent plastic products. }\end{array}$ \\
\hline
\end{tabular}

The VEKA company, a leader in the design and manufacturing of window and door systems made of high-quality plastic, suggests another classification. It distinguishes several groups by the following indicators: total area of glazed surfaces on the facade of a building; design solution and mechanism of load resistance; translucent elements of glazing used in vertical light openings in external walls. These groups include:

- Window units used in small light openings in walls. 
- Ribbon glazing along the length of a facade, covering the height of one story, with a non-transparent window apron and header.

- Panoramic glazing, covering the floor-to-floor height of one story.

- Suspended translucent facade structures.

- Translucent structures for the glazing of projecting and recessed balconies (Architectural solutions for translucent structures made of VEKA profile systems,2011).

In the book "Buildings and structures with translucent facades and roofs. Theoretical foundations for the design of translucent structures", the Institute of Construction and Architecture of the Moscow State University of Civil Engineering distinguishes three groups of suspended translucent facades by their design and method of construction.

- mullion-transom systems;

- unitized (modular) facades;

- spider systems.

Mullion-transom and modular facades are divided into the following subgroups (by method of translucent glazing (glass unit) attachment to the elements of a profile system):

- standard (with the mechanical attachment of glass units);

- structural (with a bonded glass unit) (Boriskina, 2012).

Based on the analysis of these classifications, the following can be concluded: the classification suggested in the state standard is rather complex and disorganized, and it actually presents several classifications by different criteria (without any clear idea of glazing options); for convenience, the classifications suggested by the Institute of Construction and Architecture of the Moscow State University of Civil Engineering and the VEKA company are simplified to the maximum extent but they do not cover all types and methods of glazing used nowadays. The classification suggested by the VEKA company has no unified criterion to distinguish between types of glazing.
It is based on various aspects: from architectural and geometric to heat-engineering characteristics.

\section{Tasks and methods}

The tasks of the study are the following:

- to analyze various systems of translucent enclosures (based on national and international experience);

- to identify the form-generating potential for various types of such facades;

- to systematize data and develop an updated classification for translucent enclosures;

- to determine aspects of providing an interaction between the external and internal environment with the use of translucent enclosures based on their structural and technical specifications as well as factors of the external environment.

The methodological basis of the study is a comprehensive approach including:

- analysis of architectural objects designed with account for the use of translucent facade structures;

- comparative analysis of different approaches to the design of architectural space;

- analysis of the relevant scientific and regulatory literature;

- comparative analysis of principles, tools, and methods of the design of building with translucent enclosures;

- classification of the identified types of glazing;

- graphical and analytical analysis of translucent facade structures.

\section{Results and discussion}

With a view to the disadvantages of the existing classifications described above, in their work titled "Energy efficiency of buildings and structures with translucent constructions", Fedorov and Lazina suggested a new classification for translucent facade structures (Figure 1).

\section{Types of facade glazing}

\begin{tabular}{|c|c|c|c|}
\hline $\begin{array}{l}\text { Glazing using a } \\
\text { mullion-transom } \\
\text { system } \\
\text { a) Attachment to the } \\
\text { frame } \\
\text { - mullion-transom } \\
\text { glazing; } \\
\text { - mullion glazing; } \\
\text { - transom glazing. } \\
\text { b) Availability and } \\
\text { size of pressure } \\
\text { plates } \\
\text { - glazing with } \\
\text { pressure plates; } \\
\text { - glazing without } \\
\text { pressure plates. }\end{array}$ & $\begin{array}{l}\text { Profile glazing } \\
\text { - wooden profiles; } \\
\text { - aluminum } \\
\text { profiles; } \\
\text { - plastic profiles; } \\
\text { - composite } \\
\text { material profiles. }\end{array}$ & $\begin{array}{l}\text { Point-fixed glazing } \\
\text { (planar glazing) } \\
\text { - attachment directly } \\
\text { to enclosures; } \\
\text { - attachment using } \\
\text { plane structures; } \\
\text { - attachment using } \\
\text { spatial structures. }\end{array}$ & $\begin{array}{l}\text { Glazing with the } \\
\text { use of structural } \\
\text { glass } \\
\text { - glass brick; } \\
\text { - U glass; } \\
\text { - full glazing with } \\
\text { laminated glass } \\
\text { (adhesive base). }\end{array}$ \\
\hline \multicolumn{4}{|c|}{ Combined glazing } \\
\hline
\end{tabular}


The suggested classification has the following advantages and distinctions:

- it covers all types of facade glazing used nowadays, combining existing developments in the area, considering modern trends of scientific progress and new manufacturing capabilities;

- it introduces a new type of combined glazing, taking into account the possibility of using complex combinations of various design solutions in a facade;

- it differentiates types of facade glazing mainly by design, which determines the appearance of facades to a great extent (therefore, it is important for architects to understand the specifics of this feature);

- it allows for changes and modifications (it is possible to update and supplement data with a view to technological development and constant search for new trends in facade glazing).

The first type of facade glazing - glazing using a mullion-transom system - involves translucent facades where mullions and transoms are load-bearing elements. Mullions and transoms (i.e. a frame) ensure the attachment of the structure to load-bearing members of a building. A glass unit is attached to the load-bearing frame using pressure plates, above which decorative cover caps are installed. As a consequence, the translucent plane on a facade is divided into individual parts. Combining joints of mullions and transoms, it is possible to integrate tilt-andturn structures and entrance units into a facade, create a pyramidal structure on the top of a building, assemble curved glazing. Vertical and horizontal load-bearing profiles of the mullion-transom system can be joined in several ways. Therefore, it is possible to choose a joint depending on a particular facade.

Mullion or transom attachment is also possible. In this case, the interaction between the internal and external space strengthens as the area of the non-transparent part reduces. The scope of view of the external space expands for those located inside. Outside, typical dynamics is observed (stylistic and visual elements directing upwards and sideways).

With the appearance of extra-strong silicone sealants, it became possible to glaze facades with no (or with partial) mechanical attachment of glass (a glass unit) to the load-bearing frame. Such sealants are characterized by excellent adhesive properties. They are UV resistant and can withstand rapid changes in temperature. If no mechanical attachment of translucent glazing is provided, there is no need for pressure plates. The space between glass units is hermetically filled from outside: a structural joint is formed (that is why in many sources such glazing is called "structural glazing" (Smirnov, 2005)). In case of partial mechanical attachment (combined, with the use of a sealant), narrow and almost invisible pressure plates are used, which simulate the structural joint (Alutech Group. ALT F50 mullion-transom facade. Available at: http://www. alutech-group.com/product/profiles/f50/stoechno-rigelnyfasad/; Schittich et al., 1999). Through the use of such glazing, a building is seen as a single piece. Visually, it becomes light and smooth (Table 1).
If two-pane windows or single plate glasses are used, the mullion-transom glazing system is considered "cold". It is applied in warm-climate regions. In a cold climate, three- and four-pane windows with an inert gas between the panes ("warm" glazing) are used (Fedorov and Lazina).

Profiled glazing in translucent facades is represented by floor-to-ceiling window systems. Profiles used in such glazing can be aluminum, wooden, or plastic.

Modern wooden windows are a synthesis of the latest technologies and eco-friendly materials, which make it possible to produce non-toxic reliable structures with beautiful appearance. Wooden window crossbars are usually used indoor under dry, normal, or wet conditions. The cost of wooden windows is higher than the cost of plastic ones as wood requires long-term drying, thorough treatment with a preservative, and moisture protection. Duly treated wood is a durable and reliable material. Among the main advantages of wooden profile systems, the following can be distinguished: environmental friendliness and better heat-engineering performance (as compared with windows with plastic and metal profiles).

The concept of manufacturing and using modern plastic profiles reduces to a compromise between the cost and high quality of a product. Choosing a plastic profile, it is necessary to pay attention to the frame sealing. The frame shall have two sealing strips. Otherwise, condensate will accumulate under the frame, deteriorating the insulation and creating a perfect environment for bacteria and mold to grow. Hollow sections in a profile improve its heatinsulation properties. Due to its weather-proof properties, PVC does not absorb moisture, swell, decay, or crack.

Aluminum windows are characterized by high strength, a reliable structure, and long service life. They are often used in public facilities and residential buildings. Like other metals, aluminum is non-combustible, can withstand rapid changes in temperature and heavy static loads. Moreover, it is lightweight, so it is a perfect choice for window manufacturing. Modern technologies of window frame manufacturing from aluminum profiles, significantly reducing heat transfer in the material, achieved particular progress. That is why recently aluminum windows have become popular in individual housing construction, glazing of recessed balconies and structural additions (Table 1).

Such glazing is limited by height as it is mounted between floor slabs. Thus, we see a clear floor-by-floor division of glazed facade parts from outside.

The principle of point-fixed (planar) glazing is in the following: glass is attached to a spider - a spatial bracket made of high-alloy steel - through drilled holes (Schittich et al., 1999). The spider bracket is fixed to frame posts, transmitting the load to them. The load-bearing structure of such glazing is represented by plane and spatial systems (Smirnov, 2004). Plane load-bearing systems include steel tube trusses, vertical posts, rod and cable trusses, vertically extended ropes. Spider glazing with the use of ropes is one of the most attractive systems. However, due to complex structural analysis and assembly, it is the most expensive as well. Spatial systems include pyramidal strut structures and grids. Finally, attachment 
of a suspended glazed facade directly to enclosures (to a wall) is the simplest way of attaching translucent material with fasteners. The lack of load-bearing frames between glass panels is the main distinction of planar glazing, and the possibility to highlight a unique building style is its main advantage (Table 1).

Using a spider structure, it is possible to mount glazing by joining panels at any required angle. In this case, the load is uniformly distributed by all fixation points. Planar glazing is not limited by height and has an advantage over two other types of facade glazing: fixation points of translucent glazing make a structure lighter and ensure a smooth interaction between the internal and external space. It is mainly used for "cold" facade glazing or as an additional facade layer for decorative and heat-insulation purposes.

Glazing with the use of structural glass includes glass brick, $U$ glass, and full glazing with laminated glass (adhesive base).

Glass brick is used in civil buildings to form translucent openings without crossbars (e.g. in walls of a stairway). Window openings filled with glass bricks are characterized by soundproofing, durability, fire-resistance, good illuminating properties, and soft diffused lighting. Glass brick glazing also ensures tight enclosures, improves resistance to heat transfer, and reduces the penetrating heat radiation. Moreover, glass brick is a hygienic material that requires less costs for maintenance. To compensate for temperature deformations between the glass brick enclosure and the wall, gaps filled with elastic materials are provided, and reveals are plastered (Lazarev, 2009).

$U$ glass represents $U$-shaped glass beams with a thickness of 6 or $7 \mathrm{~mm}$ and a length up to $7 \mathrm{~m}$. They are used to construct internal and external light-diffusing glass partitions, facade enclosures. The element structure consists of a visible beam part and side plates. Glazing can be single, double, or triple. In case of double glazing, beams are mounted in pairs, with their side plates directed towards each other. Together they form a rectangular tube, or a glass block (Pilkington U glass. Available at: http:// www.slate.ru/catalog/pilkington).

With the frosted glass (in glass brick and $U$ glass), it is possible to "barricade" against the external world, preventing glances inside. Soft diffusing beams of light still pass through the glazing.

Full glazing with laminated glass (adhesive base) is a facade structure where just one material (triplex (laminated glass)) is used to form enclosing glass units and vertical load-bearing stiffeners with an adhesive base. Such glazing is characterized by the lack of other materials and fasteners, which makes it possible to look through the glass easily. Buildings with such glazing immediately catch the eye. It is as if they are weightless and transparent (Table 1).

\section{Conclusion}

The active implementation of modern translucent enclosures in architecture is conditioned both by their formgenerating potential and by the provision of an interaction between the external and internal space. Sometimes, the external environment represents a determining factor in construction. The beauty of the waking spring nature, clear summer sky with the bright sun shining, the riot of autumn colors, and winter monochrome landscapes are the reasons for glazing in private residential buildings. People tend to commune with nature in the urban environment, increasing areas of transparent structures, providing visual access to the sky, natural lighting and the urban structure in general.

The structures described above can be presented in the form of a systematic table.

\section{Table 1. Types of facade glazing}

\begin{tabular}{|l|c|c|}
\hline \multicolumn{1}{|c|}{ Types of facade glazing } & \multicolumn{1}{|c|}{ Drawing } \\
\hline $\begin{array}{l}\text { Glazing using a mullion-transom system } \\
\text { a) Attachment to the frame } \\
\text { - mullion-transom glazing; } \\
\text { (Example in architecture: Mercury City } \\
\text { Tower, } \\
\text { Moscow, Russia. } \\
\text { Architects: F. Williams, M. Posokhin, G. } \\
\text { Sirota) }\end{array}$
\end{tabular}


- mullion glazing;

(Example in architecture: Çimtaş

Administrative Offices, Bursa, Turkey.

Architect: Mimarlar ve Han Tümertekin)

- transom glazing;

(Example in architecture: Saint Petersburg

Plaza business complex,

Saint Petersburg, Russia.

Architects: E. Gerasimov,

S. Choban)

b) Availability of pressure plates - glazing with pressure plates;

(Example in architecture:

GlaxoSmithKline Canadian Head Office,

Quebec, Canada.

Architects: Coarchitecture)

- glazing without pressure plates.

(Example in architecture: Federation

Tower.

Architects: S. Choban, P. Shveger)

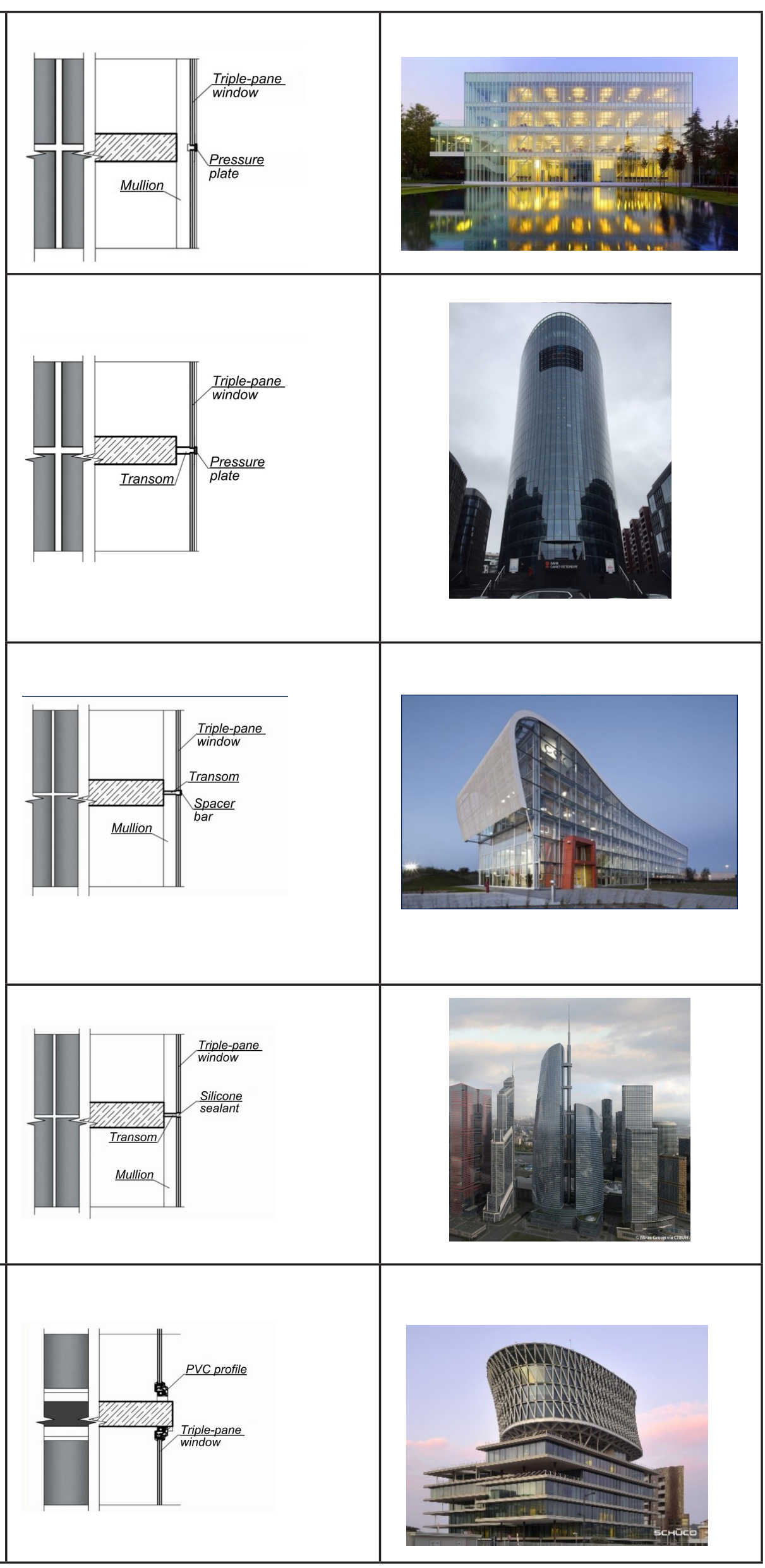

Profile glazing

- wooden profiles;

- aluminum profiles;

- plastic profiles.

(Example in architecture: Polo Direzionale De Cecco business center, Pescara, Italy. Architect: M. Fuksas) 


\section{Architecture and Engineering Volume 4 Issue 4}

Point-fixed glazing

(planar glazing)

- attachment directly to enclosures:

(Example in architecture:

National Library of Belarus.

Architects: M. Vinogradov,

V. Kramarenko)

- attachment using plane structures;

(Example in architecture: Sandro Penna

Library, Perugia, Italy.

Architect: Italo Rota)

- attachment using spatial structures.

(Example in architecture: Berlin Central

Train Station, Germany.

Architects: Gerkan, Marg \& Partners)
- U glass;

(Example in architecture: glass building on the bank of the Mississippi River,

Louisiana, USA. Architects: Trahan Architects)

- full glazing with laminated glass (adhesive base).

(Example in architecture: Helsinki Central Library Oodi, Finland.

Architects: ALA Architects)

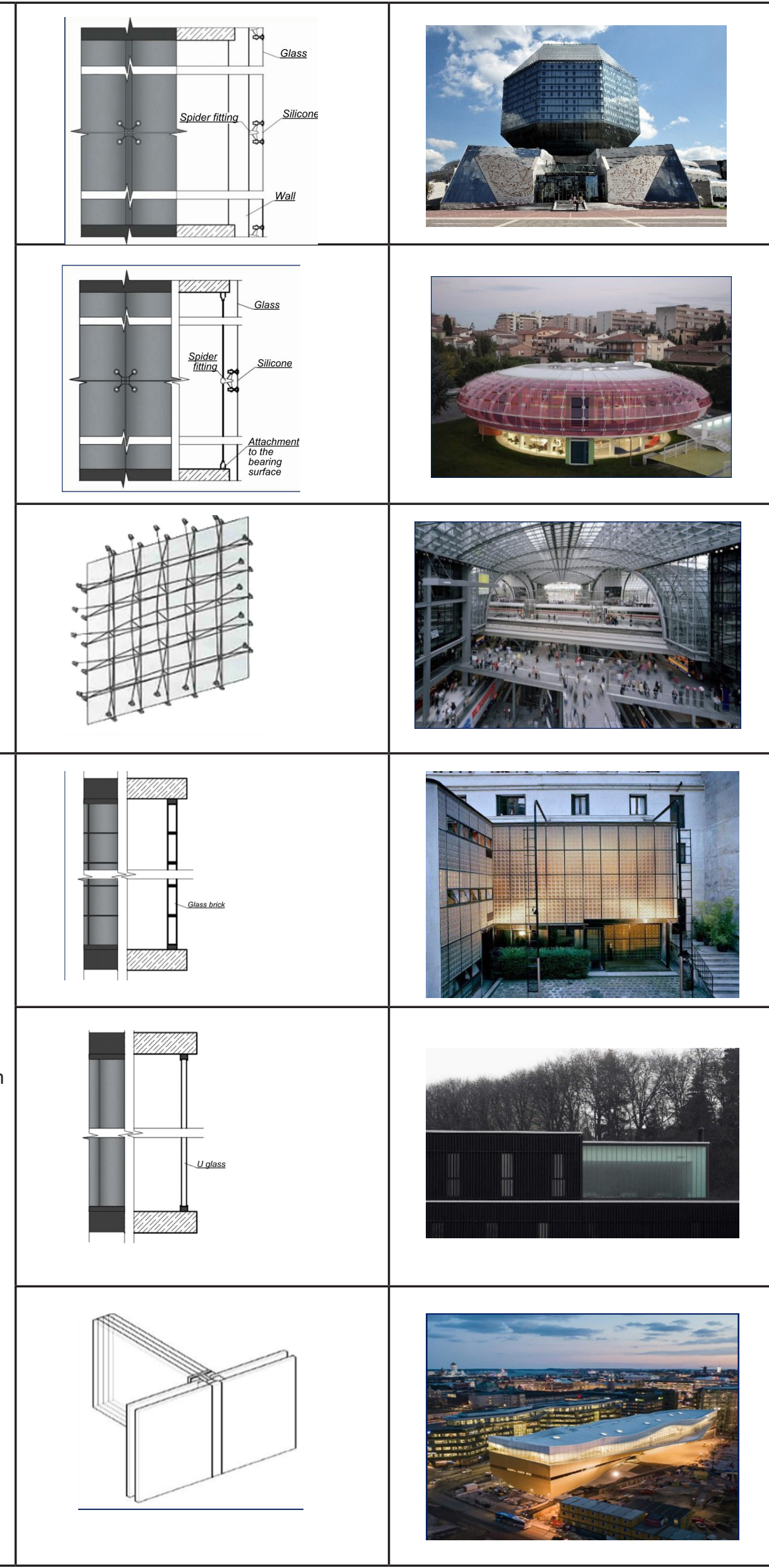


Due to its advantages listed as well as a wide range of design solutions and visual-and-decorative solutions, glass is one of the most demanded materials in construction. In terms of energy-efficient construction, these advantages are especially relevant. Using those, it is possible to ensure maximum energy efficiency, reduce heat losses and energy costs, preserve and improve visual characteristics (Great Glass Buildings; Fedorov, 2016). As long as the daylight lasts, it is light in buildings with glazed facades. This makes it possible to save energy and enjoy natural lighting (Fedorov et al., 2017).

It is hard to imagine modern architecture without glass surfaces. It first of all concerns business centers, industrial and commercial structures. Their gleaming facades and display windows are presentable and impressive. There are many unique buildings and structures in the world
(Lonescu et al., 2015) we shall still be able to enjoy even from indoors. Translucent structures ensure visual access to the sky, natural lighting, the urban structure, and the beauty of the landscape.

Each of the described types of glazing has its own set of characteristics and scope of application. Knowledge of existing possibilities and specifics of using such structures is a key to the solution of architectural tasks related to lighting, the microclimate in buildings, their energy-efficiency indicators, and visual quality (decorative characteristics, aesthetics, and architectural composition). New types and methods of glass manufacturing constantly emerge, offering architects great opportunities, mainly in terms of expressiveness. That is why it is so important to choose the type of facade glazing based on the idea of the visual effect of a future building or structure. 


\section{References}

Alutech Group. ALT F50 mullion-transom facade. [online] Available at: http://www.alutech-group.com/product/profiles/f50/stoechno-rigelny-fasad/ (accessed on: 20.02.2016).

Archi.ru. [online] Available at: https://archi.ru/ (accessed on: 02.04.2019).

Architectural solutions for translucent structures made of VEKA profile systems. (2011). [online] Available at: www.oknaprof.info (accessed on: 04.04.2019).

Boriskina, I.V. (ed.) (2012). Buildings and structures with translucent facades and roofs. Theoretical foundations for the design of translucent structures. Saint Petersburg: Engineering and Information Center of Window Systems, $400 \mathrm{p}$.

Fedorov, O.P. (2007). Decorative and ornamental use of glass in modern architecture. In: Challenging Issues of Modern Construction. Proceedings of the $60^{\text {th }}$ International Scientific and Practical Conference of Young Scientists. Part 2. Saint Petersburg: Saint Petersburg State University of Architecture and Civil Engineering, 208 p.

Fedorov, O.P., Alekseyeva, D.V., Bedzhanyan, A.G. (2015). Light as a way of expression in architecture in different historical periods. In: Challenging Issues of Architecture. Proceedings of the $68^{\text {th }}$ International Scientific and Practical Conference of Students, PhD Students, Young Scientists, and Second Doctorate Students. In 2 parts. Part 1. Saint Petersburg: Saint Petersburg State University of Architecture and Civil Engineering, 318 p.

Fedorov, O.P. (2016). Method of predicting green architecture trends based on analysis of international environmental certification systems in architecture. Fundamental Research, No. 11, Part 1, pp. 90-95.

Fedorov, O.P., Mel'nikova, E.A., Doncova, M.G. (2017). Architectural arrivals and decisions for designing sustainable architecture. In: Challenging Issues of Architecture. Proceedings of the $70^{\text {th }}$ All-Russian Scientific and Practical Conference of Students, PhD Students, and Young Scientists. Saint Petersburg: Saint Petersburg State University of Architecture and Civil Engineering, pp. 229-233.

Fedorov, O.P., Lazina, V.V. (2018). Glass in architecture as a tool to work on the architectural plan. In: Modern Problems of History and Theory of Architecture. Proceedings of the $4^{\text {th }}$ Scientific and Practical Conference. Saint Petersburg: Saint Petersburg State University of Architecture and Civil Engineering, pp. 165-173.

Fedorov, O.P. and Lazina, V.V. (2017). Energy efficiency of buildings and structures with trans/ucent constructions. Saint Petersburg: State Petersburg State University of Architecture and Civil Engineering. student research project. UDC: 624.014:748.5:620.97

Great Glass Buildings - Malestrom. Image selection.

Interstate Council for Standardization, Metrology and Certification (2015). State Standard GOST 33079-2014. Translucent enclosing structures. Classification. Terms and definitions. Moscow: Standartinform, $16 \mathrm{p}$.

Lazarev, A.G. (2009). Architecture, construction, design. Rostov-on-Don: Phoenix, 316 p.

Lonescu, C., Baracu, T., Vlad, G.-E., Necula, H., Badea, A. (2016) The historical evolution of the energy efficient buildings. Renewable and Sustainable Energy Reviews, Volume 49, pp. 243-253. DOI: 10.1016/j.rser.2015.04.062.

Schittich, C., Staib, G., Balkow, D., Schuler, M., Sobek, W. (1999). Glass construction manual. Birkhäuser - Publishers for Architecture, $328 \mathrm{p}$.

Smirnov, A.A. (2004). Designs of planar facades. Stroyprofile, No. 4-04, p. 46.

Smirnov, A.A. (2005). Designs of structural facades. Stroyprofile, No. 4-05, p. 30.

Steinwerk. Pilkington U glass. [online] Available at: http://www.slate.ru/catalog/pilkington (accessed on: 30.03.2019). 


\title{
СОВРЕМЕННЫЕ ВИТРАЖНЫЕ ОГРАЖДАЮЩИЕ КОНСТРУКЦИИ В АРХИТЕКТУРЕ
}

\author{
Олег Павлович Фёдоров ${ }^{1}$ Виктория Вадимовна Лазина² \\ ${ }^{1,2}$ Санкт-Петербургский государственный архитектурно-строительный университет \\ 2-ая Красноармейская ул., 4, Санкт-Петербург, Россия \\ 1E-mail: oleg_proart@mail.ru
}

\section{Аннотация}

Введение. В исследовании изучены, использующиеся на данный момент в архитектуре и строительстве, виды светопрозрачных ограждающих конструкций. Приводятся современные классификации таких конструкций и обозначаются их недостатки. К внедрению предлагается авторская классификация, объединяющая и систематизирующая существующие на сегодняшний день различные виды витражных светопрозрачных конструкций. Приводятся примеры объектов с соответствующими решениями. Цель исследования. Систематизация и актуализация классификации витражных ограждающих конструкций разных типов, определение их роли и места в формировании архитектуры зданий, обеспечении взаимосвязи внешней и внутренней среды, выявление формообразующего потенциала таких конструкций. Методы. Системный многофракторный подход к исследуемому вопросу, изучение и систематизация научных, архитектурно проектных источников с целью анализа сооружений, спроектированных с учетом использования светопрозрачных фасадных конструкций. Приведено описание каждого типа конструкции и в табличной форме представлены графические схемы и проекты известных архитекторов, представляющие описанные виды фасадных систем. Результаты. Определён формообразующий потенциал стеклянных конструкций; проанализированы роль и место светопрозрачных витражных ограждающих конструкций в формировании архитектуры зданий, обеспечении взаимосвязи внешней и внутренней среды; разработана новая классификация современных типов витражных фрасадов по архитектурно-конструктивному признаку.

\section{Ключевые слова}

Светопрозрачные витражные ограждающие конструкции, свет, стекло, фрасад, система остекления фрасада, классификация. 